\title{
Construction of Practice System of Innovation and Entrepreneurship Education in Sports Colleges and Universities
}

\author{
Yadong Ren \\ (Huaiyin Normal University ,223300,Huai'an,Jiangsu,China) \\ jlryd@163.com
}

Keywords: Higher sports colleges; Innovation and entrepreneurship; Practice system

\begin{abstract}
Innovation and entrepreneurship education, as an educational idea and educational carrier, emphasizes that students are the main body of education, and based on entrepreneurial needs, they develop and train students' entrepreneurial potential, and position themselves for future entrepreneurial activities. In terms of physical education students, although they have strong physical stamina, tough mentality, and entrepreneurial qualities that they dare to challenge, they generally lack entrepreneurial awareness, entrepreneurial knowledge, and entrepreneurial skills, making it difficult to open up new business opportunities in sports industries that are full of opportunities and challenges. Therefore, this article analyzes the status quo of innovation and entrepreneurship education in higher institutes of sports, analyzes its main problems and constraints, combines the reality of sports colleges and universities, and proposes a practice system of innovation and entrepreneurship education based on training to improve the entrepreneurial skills of college students. In order to provide innovative and entrepreneurial practice activities for sports colleges and universities, provide reference and education paradigms.
\end{abstract}

\section{Introduction}

The employment of colleges and universities has brought unprecedented pressure to the employment of students. The employment of college students has become an important issue of concern to colleges and society. In order to solve the employment pressure of students, broaden their employment opportunities, and improve the quality of student employment, innovative entrepreneurship training programs are particularly important for colleges and universities. Colleges and universities are required to speed up the development of innovation and entrepreneurship education, and deepen innovation and entrepreneurship education reform. It is scientific, advanced, and identifiable, has the concept of innovation and entrepreneurship education with Chinese characteristics, and is widely promoted and popularized in colleges and universities. The innovation and entrepreneurship of undergraduates in the new era have become the trend of the teaching reform in colleges and universities. Physical education colleges must also cater to the needs of teaching reform, combine the advantages of the profession, actively carry out the construction of a comprehensive system of innovation and entrepreneurship education, and establish a sustainable development of physical education institutes within and outside schools. The school's innovation and entrepreneurship education system has enabled students' awareness of innovation and entrepreneurship and their entrepreneurial ability to be significantly improved, so as to increase the number of entrepreneurs in sports colleges and create an entrepreneurial atmosphere in schools. It is in line with the needs of the times to build a comprehensive system of innovation and entrepreneurship education in a diverse, multi-level, interdisciplinary, and open sports college. The establishment of a comprehensive system of innovation and entrepreneurship education in sports academies can provide high-quality employment for students, help promote the comprehensive reform of sports academies, and improve students' innovative ideas, innovation awareness, and innovation capabilities. 


\section{The Necessity of Constructing the Innovation and Entrepreneurship Education System in Sports Colleges}

Relieve the Need for Pressure on Employment in Sports College Students. Sports colleges of higher education in the occupied an important position, the shoulder for our train outstanding physical education teachers, sports coaches the task, the sports industry executives, sports athletes. Physical education colleges have their own characteristics of running schools. Compared with ordinary colleges and universities, physical education colleges have lower admission scores, and some students with relatively weak cultural classes tend to apply for sports colleges. With the increase in the number of applicants, physical education institutions have increased the number of students enrolled. Not only has the number of students enrolled in undergraduate courses increased, but the number of graduate students in sports has also increased. In the context of continuing enrollment in sports, some comprehensive universities have seen this opportunity and have also established sports institutes. The number of sports enrollment has risen nationwide. With the increase in the number of graduates of physical education, unprecedented pressure has been placed on the employment of students. Even graduate students of some sports majors compete in primary and secondary schools and undergraduates. A PE teacher's position is often competed by hundreds of people, and the employment position of PE teachers is very limited and cannot meet the needs of graduates. Graduates cannot find the ideal job and are forced to change jobs that are inconsistent with their own profession. The student's high-quality employment rate is low, and students' satisfaction with the current job is not high.

Fostering the Need for Innovative Applied Sports Talents. Physical education colleges and universities, as leading institutions in the field of industry, have always followed the traditional training mode in their talent cultivation. They focus on the cultivation of students' practical abilities and their ability to innovate and innovate. The survey found that the majority of sports institutes nationwide are not popular in innovation and entrepreneurship education. Only a few sports colleges have set up compulsory courses or elective courses for innovation and entrepreneurship education, and established sports college students to start businesses. The base provides students with entrepreneurial guidance. However, most colleges and universities still only hold some entrepreneurial plan competition events and carry out some innovation and entrepreneurship seminars. They did not really incorporate innovation and entrepreneurship education into the sports professional talent training system. The quality of personnel training in sports colleges and universities has not been able to meet the current social needs of sports talents. China is in a period of rapid economic development, which provides an opportunity for the development of China's sports industry. During the development of the sports industry, a large number of employment opportunities are provided for students majoring in physical education, and there will be more and more demand for talents for sports "dual-creation", which puts forward higher requirements for personnel training in sports colleges. Sports institutions should seize this opportunity to strengthen the cultivation of innovative sports talents.

To Promote the Sustainable Development Needs of Sports Disciplines. In response to problems in the expansion of enrollment and graduate employment in universities, the Ministry of Education has tightened the restrictions on enrollment plans and enrollment professionals in colleges and universities. Some of the less-employed majors appear to have reduced enrollment or stopped enrollment. In the new situation in which colleges and universities across the country experience a decrease in enrollment and abolition of the low-employment professional, physical education institutions also face the biggest challenge in the process of running a school. How to promote the sustainable development of the physical education profession has become an important topic for research in sports academies. With the change of China's industrial structure, the demand for sports talents in society has also changed, and the demand for some physical education teachers and sports administrative posts has decreased. At the same time, the requirements for post-graduate education and ability have gradually increased. The sports industry to the economy as the main battleground radiation more than other areas of the current form of employment patterns, so that the 
sports professional graduates more difficult. Graduates of sports colleges are faced with the challenge of diversified development of employment positions and employment methods.

\section{Analysis of Main Problems Existing in Innovation and Entrepreneurship Education in Sports Colleges and Universities}

Any education process can not be separated from the main body of education - educators, students can not be separated from the object - students, but also inseparable from the implementation of education organizations and security systems. There are three problems in the innovation and entrepreneurship education in higher physical education colleges.

Lack of Understanding of the Necessity of Innovation and Entrepreneurship Education. The vast majority of educators have misunderstandings about innovation and entrepreneurship education and believe that "only by strengthening the professional skills of students can we help careers after graduation"; we believe that "the success rate of undergraduate entrepreneurship is low, and the establishment of entrepreneurial courses not only accounts for the number of hours of class. And that the effect is not high; "think that sports students have a single knowledge structure, lack of entrepreneurial skills, and few opportunities for entrepreneurs to start their own business," reflecting their lack of thorough understanding of the connotation of innovation and entrepreneurship education, and the difficulty in integrating innovation and entrepreneurship education concepts.

Lack of Innovation and Entrepreneurship Education System. Since innovation and entrepreneurship education has not yet established a clear disciplinary system and professional setting in China, most colleges and universities did not really integrate the innovation and entrepreneurship education into the curriculum system of professional talents training programs, and lacked the necessary management systems, teaching staff, and supporting materials. There is a lack of necessary institutional construction. It is precisely these institutional constructions that are effective for the implementation of innovation and entrepreneurship education and play a role of guarantee and promotion.

Lack of Innovation and Entrepreneurship Education and Teaching Mechanism. At present, in order to respond to the call, we have been forced to open employment guidance classes, social etiquette lessons, and employment seminars to create a business plan competition for the creation of an entrepreneurial atmosphere. However, due to the inaccurate market analysis data of the business plan, the feasibility and operability are not. Strong, far from planning ideas for starting a new company. Even though some colleges and universities have carried out some practice activities in innovation and entrepreneurship education inside and outside the school, they are not specific, the model is not standardized, and the formalization is serious. It cannot really tap the potential of students' entrepreneurship and cultivate the educational effectiveness of students' entrepreneurial ability. Practice has proved that establishing an innovative and entrepreneurial education teaching mechanism that suits the actual conditions of the school is an effective way to cultivate entrepreneurial sports talents.

\section{Basic Ideas for Establishing a Practice System of Innovation and Entrepreneurship Education in Higher Physical Education Colleges and Universities}

Innovation and entrepreneurship education, broadly speaking, is an educational practice activity that creates a new career. It is a groundbreaking individual who cultivates initiative, pioneering awareness, entrepreneurial ability, social and management skills; in a narrow sense, it is about Create a new career or new job education and teaching practice. Its core and connotation are the research on human creativity, pioneering, professionalism and pioneering ability. From the perspective of the discipline system, innovation and entrepreneurship education has a clear teaching orientation and training objectives. And the unique educational values, knowledge structure and ability to operate the program, the education system works on the culture of innovation and entrepreneurial talent. From this we can see that innovation and entrepreneurship education has 
distinct characteristics from traditional education. It is not only necessary to teach student entrepreneurial knowledge through a theoretical teaching system, but also to cultivate and hone entrepreneurial ability through a practical teaching system. Therefore, the author believes that it is necessary to break the boundary between the relatively independent curriculum teaching system and the practical teaching system, as well as the practical teaching content requirements of "broad sense" and "narrow sense", and adopt the concept of "innovative and entrepreneurial education teaching practice". That is when building innovation and entrepreneurship teaching practice system of education, the teaching program inside and outside, inside and outside of the classroom teaching activities for everything the educated set, is called "teaching practice", are brought together innovation and entrepreneurship education practice teaching system.

Sports practice innovation and entrepreneurship education system is through innovation and entrepreneurship courses, business simulation practice, social testing exercise, the second classroom activities, community activities, professional practice education model that allows students to master the basics of entrepreneurship, social contact all walks of life, to understand the sports industry development prospects, improve professional practice, rich social experience, social skills training, enabling sports science and technology innovation and market innovative venture to serve the country in the socio-economic field of sports. The core of the system is to establish an education system platform for the development of sports undergraduates' innovative and entrepreneurial qualities, tostrengthen the practical application of professional skills, to try out entrepreneurial activities, and to cultivate entrepreneurial qualities. This is the guiding ideology and end-result of the author's practice system for innovation and entrepreneurship education in higher physical education institutions.

\section{Construction of Practice and Education System for Innovation and Entrepreneurship in Sports Colleges and Universities}

Classroom Simulation Business Practice Model. Classroom entrepreneurship practice is the process of establishing entrepreneurial teams, looking for business opportunities, formulating entrepreneurial plans, and experiencing the entire process of entrepreneurship. Students can learn entrepreneurial skills such as entrepreneurial knowledge, entrepreneurial methods, cooperative awareness, and risk awareness in practice. According to the purpose of teaching, it is divided into no role model and role simulation. Character entrepreneurship simulation is the teacher designing the entrepreneurial classroom environment, demonstrating entrepreneurial skills and operating procedures, students are free to compose a simulation team, from the design of the store name, find the location of the shop, discuss the budget, design and develop advertising, forecast sales targets, judge the sales amount, etc. In terms of the conception and design of the entrepreneurial program, the teacher conducts role-based entrepreneurship simulation after auditing. After the class, each team must carefully scrutinize each practice, write an internship report, and submit it for review.

Professional Practice Business Practice Model. The practice model of entrepreneurship based on professional internship is based on the main goal of innovation and entrepreneurship education. Students are allowed to take jobs and participate in internships to cultivate students' entrepreneurial awareness, entrepreneurial quality and entrepreneurial ability. Specific implementation process First, choose the internship unit, pre-internship on campus. According to the objectives and tasks of professional internship, the internship organization is selected, and a detailed internship plan is developed from the internship content and form. In conjunction with the work requirements of the internship organization, pre-internship is conducted on campus. Second, enter the internship unit and enter the internship system. Third, write an internship report and accept the assessment. The students comprehensively and systematically summarized the changes in thinking, psychological quality, knowledge structure, professional skills, and internship results, wrote internship reports, and refined the results of internships.

Social Service Entrepreneurship Practice Model. Make full use of resources inside and outside the school such as stadiums, companies, companies, sports clubs, fitness centers, community service centers, etc., use spare time, rely on student clubs or clubs as carriers, conduct 
innovation and entrepreneurship service activities, and establish diversification inside and outside the school Service innovation mode of entrepreneurship education. Students rely on schools or self-created innovation and entrepreneurship social squads, through social surveys, participation in corporate production, company sales or management, community service and professional guidance, etc., to gain an in-depth understanding of the needs of the society and the labor market, to recognize occupations, to experience occupations, and to accumulate entrepreneurial experiences In order to learn how to find and grasp opportunities, how to conduct market research, cost accounting, product production and marketing, how to build a successful entrepreneurial team, how to deal with risks and setbacks, how to combine professional advantages to start a business, etc., to cultivate and improve entrepreneurial ability and quality.

\section{Conclusion}

One of the core problems to be solved urgently is the popularization and development of innovation and entrepreneurship education. Therefore, the higher sports colleges and universities must take a brand new educational value orientation, through rational integration, harmony and sublimation, realize the coupling of innovation and entrepreneurship education and professional education, effectively and effectively through innovation and entrepreneurship education, improve the comprehensive quality of sports college students, and promote them to become professional posts by the simple employment. Creators and pioneers and operators of sports in the new era. This is more prominent and important for serving the construction of an innovative country. It will play an unprecedented role in promoting the employment situation of sports college students.

\section{References}

[1] Song X J. Construction of Ecological System of Innovation and Entrepreneurship Education in Colleges and Universities[J]. Value Engineering, 2016.

[2] Wang X H. On the Cultivating Functions of Innovation and Entrepreneurship Education in Colleges and Universities[J]. Journal of Changzhou Vocational College of Information Technology, 2012, 3(1):50-54.

[3] Jiang $\mathrm{H}$, Yin $\mathrm{H}, \mathrm{Xu} \mathrm{X}$. Research on the Mode of Cultivating Talents of Innovation and Entrepreneurship in Colleges and Universities[J]. Journal of National Academy of Education Administration, 2015.

[4] Xiao-Hua L I, Zhang L P, Wang X F. A Research on Innovation and Entrepreneurship Education System Construction of Local Colleges and Universities[J]. Journal of Hebei University of Science \& Technology, 2015.

[5] Lian F. Research on Innovation and Entrepreneurship Education in Higher Vocational Colleges Based on qInternetPlusq[C]// International Conference on Management, Economics and Social Development. 2017.

[6] Weng F, Ke L, Ding M, et al. On Innovation and Entrepreneurship Education in Colleges and Universities of Traditional Chinese Medicine[J]. Journal of College Advisor, 2015.

[7] Chen S. Construction of Evaluation Index System of Innovation and Entrepreneurship in Local Colleges and Universities[J]. Journal of Biological Chemistry, 2016, 275(27):20748-53.

[8] Xuan L I, Xiao-Qin L I, Bai Z T. A study on the Construction of Innovation and Entrepreneurship Education Curriculum System of Xinjiang Universities and Colleges[J]. Education Teaching Forum, 2017.

[9] Huang X H. On the Practical Teaching Mechanism of Innovation and Entrepreneurship Education in Colleges and Universities[J]. Heilongjiang Researches on Higher Education, 2015.

[10] Shao M Y. Study on the Effectiveness of Innovation and Entrepreneurship Education in Higher Vocational Colleges under the Background of High Quality Colleges and Universities[J]. Journal of Hubei Correspondence University, 2017.

[11] Zhao S, Feng J. Analysis of Effective Ways to Conduct Innovation and Entrepreneurship Education at Colleges and Universities[C]// International Conference on Education, 
Management, Computer and Society. Atlantis Press, 2016.

[12] Sun H D, University A N. Study on the practice of Mao Zedong's thought on the innovation and entrepreneurship education in colleges and universities[J]. Journal of Jiamusi Vocational Institute, 2017.

[13] Wang J F. Research on the Development of Innovation and Entrepreneurship Education in Colleges and Universities in Heilongjiang Province[J]. Education Teaching Forum, 2017.

[14] Lei Z M, Department F L, University G M. Ideological and Political Education,Innovation and Entrepreneurship Education and Employment Guidance in Higher Colleges[J]. Journal of Hubei Correspondence University, 2018. 